\title{
The Role of University Education in Making Changes in Values: A Field Study Targeting the Students in King Abdulaziz University in Jeddah
}

\author{
Aqeel Hussain Al Khayri $\quad$ Dr. Khalid Tmaim
}

\begin{abstract}
The present study aimed to explore the role of university education in making changes in values from the perspective of the students in King Abdulaziz University in Jeddah. The sample consists from 390 female and male students enrolled in King Abdulaziz University in Jeddah. A social descriptive survey-based approach was adopted. It was found that university education plays a significant role in making changes in the orientations of the youth in society from the perspective of the students in King Abdulaziz University in Jeddah. It was found that there are several methods that can be employed for promoting good values through university education among university students. The mean of the area of (the significance of the values in university education) is ranked first. The mean of the area of (the motives behind promoting values through university education) is ranked second. The mean of the area of (the role of university education in changing the youth orientations in society) is third.

Keywords: University Education, Field study, students
\end{abstract}

DOI: $10.7176 / \mathrm{JEP} / 11-21-11$

Publication date:July $31^{\text {st }} 2020$

\section{Introduction:}

Education in making changes in values is already changing the individual inevitably scientific development and technical, as the general principle is the change, movement and progress of human to reconcile hard and unstable and appropriate between the principles and requirements of the renewed era, it began the modern university education in Arab societies in the first half of the twentieth century in the image of the beginnings of a modest His graduates represented a limited elite in society in terms of their number and impact.

The last quarter of the twentieth century witnessed a significant expansion in university education, It increased with the importance of the university site in preparing individuals for life and work of a specialist in public service and national production and development sectors. The stated aim of university education was not only to provide students with specialized information and knowledge and to provide them with technical and practical skills, but this education continued to emphasize the importance of developing personal, social and professional values (Halima, 2015).

it has a university education of great importance in view of the progress made to their communities from the potential and experience of education and continuous training, as higher education plays an important role in the development of society and its development through the contribution of its institutions in the graduation of trained human cadres to work in all fields of different disciplines and it became interest in him An imperative necessity because its negligence leads to a social consequence of the failure of education and if education fails, this failure has consequences and effects that reflect a negative and dangerous reflection on the economic and social situation of societies (Noor Al-Huda, 2015).

In order for higher education to succeed in achieving its role, the relationship between it and technology must be supported. The societies that wish to possess the power of science and technology need to develop a special science and technology system between simulation of international science to create, apply, accumulate and innovate science and technology and not broadcast them only, therefore the paper aims to address an issue Higher education as a lever to bring about social and economic change in society while clarifying the relationship between science and technology and the use of a descriptive approach to analyze the following axes: study concepts, the relationship of higher education to technology and their role in bringing about social and economic change in societies, employing higher education and technology to serve socio-economic change (Noor Al-Huda, 2015).

In light of the change that university education brings about, especially in spreading awareness and developing awareness of the importance of work, as young people rely fundamentally on university education in order to obtain a suitable job, there is no doubt that the university qualification is the primary key to exit to the labor market and then the person guarantees access to income It helps him to fulfill his requirements, and university education plays an important role in developing cultural awareness among members of society about issues pertaining to the homeland, which takes a large part of public opinion attention, and students also learn through and through methods and etiquette of dialogue and its ability to absorb increases. And think about good ways, and avoid randomness in decision-making.

Hence the importance of studying the location of values in university education to reveal the efforts made to take care of the topic of values in university education legislation and practices. And if university graduates 
practice their work in society on the basis of the specialized knowledge and skills provided to them, then this is actually done within a framework of values that determine their behavior and attitudes towards life and towards society.

Hence, the researcher was able to determine the problem of the study in asking about the role of university education in the value and social change in Saudi society, starting from the idea that there are rapid changes that have swept the Saudi society in recent years, affecting the Saudi society.

\section{The problem of the study:}

Any phenomenon is organically linked with the community stems from the interaction of two sets of internal and external variables, and this applies to the role of university education in the community on the grounds that the university vary in their roles from one society to another, since the Saudi society engaged in the modernization and change of values, either positive or negative Hence, the researcher was able to determine the problem of studying in the question, what is the role of university education in the value change from the viewpoint of students of King Abdulaziz University in the city of Jeddah?

\section{Study questions:}

- What is the extent of the impact of university education on bringing about a value change in Saudi society from the viewpoint of students of King Abdul-Aziz University in the city of Jeddah?

- Is there a statistically significant relationship in the role of university education in the change in Saudi society due to the gender variable, age, and educational level from the viewpoint of students of King Abdulaziz University in the city of Jeddah?

\section{Objectives of the study:}

\section{The main objectives of the study are as follows:}

1. Determine the extent of the impact of university education in bringing about moral change in Saudi society, from the perspective of students, the University of King Abdulaziz, in the city of Jeddah.

2. Explaining the role of university education in changing the attitudes of young people in society from the viewpoint of students of King Abdulaziz University in the city of Jeddah.

3. To determine the relationship between the role of university education in the moral change in Saudi society due to the variable gender, age, and place of the family residence, educational level and from the perspective of university students in the Saudi city of Jeddah.

\section{Importance of Study:}

The importance of the study stems from the fact that it tries to show the extent of the contribution of university education to the value and social change in the Saudi society, as the Saudi society is an integral part of the global system, as it affects and is affected by what is happening in the world of great social changes that change from the social building units of society, as well The importance of the study is followed by the following two aspects:

\section{Theoretical importance}

The importance of theoretical study lies in the following:

- From the nature of the topic you are dealing with, which deals with social change because of its importance in society.

- Enriching the theoretical aspect related to the role of university education in social change.

\section{Practical importance}

It is hoped that this study will provide a measure to reveal the impact of university education on the value and social change in Saudi society in the city of Jeddah.

Defining procedural concepts:

\section{The concept of value change:}

Valuable change means that it is that social activity that often takes the form of perceptions and disorganized feelings, an activity that gradually becomes expressive of new forms of belief and collective behavior, which do not find outlets to express their demands, and turn into an organized movement, important to existing social patterns (Alorikat, 2004).

The researcher defines it as defining the transformations and modifications that occur to members of society, and the status, roles, jobs, social, and civilization systems of society.

Values: A set of perceptions and concepts that form a framework for standards, judgments, ideals, beliefs and preferences formed by the individual through his interaction with individual and social situations and experiences, so that it enables him to choose goals and directions for his life and sees it as worthy of employing his capabilities and embodied through interests, trends or practical or verbal behavior in a way Direct and indirect (Abul-Enein 1988: 34). 


\section{Previous Study}

A study aimed at Abdulaziz Bin Ali Al-Gharib (2016) Entitled "Social and cultural change with practical models of Saudi society, keep track of what has been written in the social and cultural change since its inception as a concept of intellectual and began to date. This study came in several chapters that examined in each chapter an aspect of social and cultural change in the Kingdom of Saudi Arabia, and the study dealt with the issue of family change; This included the concept of family change, the changes that the Saudi family was subjected to, the change in the pattern and size of the Saudi family, the problems caused by family change, and (finally) the family and facing social change.

The study, Halima Touinat (2015) entitled "Value and directional change among higher education students moving from the countryside to the city" aimed at explaining the effect of the value and directional change in higher education students moving from the countryside to the city, where students coming from the countryside to the city to change their university studies from The normal values that they bring to negative values, due to friction in circles that encourage them to do so in university residential neighborhoods, as well as dealing in tortuous ways with some professors and employees. The students stated changing their biographies and behaviors as required by the new circumstances, and it has been clear from the applied scale that changing the values towards negativity represents $73 \%$ of students out of (627) and that the difference between those with negative and positive values is in favor of negativity, as the encouragement for this is often What is inside the university or university residential neighborhoods.

The study of Nour Al-Huda Hammad (2015) entitled "Higher Education and Technology as a Leverage for Social and Economic Change in Societies" also referred to higher education in order to succeed in achieving its role. The relationship between it and technology must be supported. Societies that want to possess the power of science and technology need to develop a system science and special technique between the simulation of the international science of creativity and application of accumulation and innovation of science and technology and not aired only by the paper aims to address the issue of higher education as a lever to bring about social and economic change in society with clarifying the relationship between science and technology, The study concluded that higher education technology and their role in bringing about social and economic change societies and bananas provide society with tools expressing their identity and achieve their development objectives. The study also recommended a review of the educational policies of higher education programs to be employed for the development of graduates capabilities to serve the problems of development With society, adopting programs for transferring science and technology that are compatible with society's values and needs, and linking theoretical knowledge with reality.

The study (Owens, et al, 2011) refers to the role of youth in bringing about change in local and regional communities. The study aims to involve young people in the Sacramento metropolitan area in exploring the issues they face in their daily lives, and identifying obstacles to their development in their societies. Young people have videos, photographs, an online map, and poetry, to express their perceptions and ideas to pass on to others, and as a result, young people have had an innovative and effective role in social change initiatives that improve their conditions and involve them in decision-making processes in their communities.

(Zumum, 2009) study titled "Valuable Change in Social Marketing Campaigns" aims to identify the most important values included in Social Marketing Campaigns in the UAE community and its relationship to the idea of Social Change. The study results have shown that various social values the first place has occupied a rate $(20.30 \%)$ of the sum of the values studied, and in terms of the strategies used in these campaigns, it has been shown from the results of the study that the behavioral campaigns have ranked first with a rate $(37.5 \%)$, and ranked behavior change first place by $57.5(\%)$ of all levels of social change.

The study (Al-Aqili, et al., 2007), entitled The role of universities in changing the political culture of students, indicates a field study at Mutah University, on a sample of (500) male and female students. By involving students in the precise and organized cognitive field of the political system, and its formal and informal political institutions in order to create a conscious generation, aware of the functions of political institutions, and dealing with them away from negativity and political indifference, the results of the study indicated that there are statistically significant differences at a distance The legislative authority is attributable to the variable (gender, college, and participation in public activity), where the average male response (12.41), and the average female (8.95), and differences came in favor of participants in public activity, where the average response of participants in public activity (11.96), The average response of non-participants (9.34), and finally, the differences came in favor of students of scientific colleges, where the average was (12.26), and the average of human colleges (9.86), and the results indicated that there were no statistically significant differences in the performance of students at the distance of the first authority Legislative attributable to the age variable.

A study (Tali Jigel, 2016) entitled "Valuable change in the university environment. A field study on a sample of university students. Journal of Social Studies and Research: It aimed to explain the effect of the university community on value change, where the study indicated the value change is characterized by multiplicity and complexity, the fact that Algerian society has never completely abandoned traditional values, with the relentless 
pursuit of modernization, but rather attempted to cross traditional with modern, which made valuable duplication be the dominant and most prominent feature of individuals in Algerian society, where the study indicated that university youth are the most impulsive social group and interact with the values of modernization Especially in the university community.

Statistical data processing methods:

The researcher used in processing the study data the statistical methods appropriate to the nature of this study as follows:

1. Pearson correlation coefficient to measure the validity of the internal consistency of the questionnaire items.

2. Cronbach's Alpha factor for calculating the stability of the resolution.

3. Frequencies and percentages to describe the study sample and determine the percentages of their answers.

4. A test of mono-contrast analysis to reveal the differences between the views of the study sample according to their personal variables.

Second: Presentation of procedures

The researcher did a questionnaire analysis; In order to define the role of university education in social and value change for King Abdulaziz University students in the city of Jeddah on the same sample, consisting of (380) individuals from King Abdulaziz University students in Jeddah, the following are the results obtained by the researcher:

\section{Construction Certification:}

To extract the significance of construction sincerity, the parameters of the correlation of the paragraphs with the field to which they belong were extracted. The paragraphs were analyzed and the personal correlation coefficient was calculated for each of the paragraphs., And the following table shows that.

Table (1)

Correlation coefficients between vertebrae and the domain to which they belong

\begin{tabular}{|c|c|c|c|c|c|c|c|}
\hline $\begin{array}{c}\text { Paragraph } \\
\text { no. }\end{array}$ & $\begin{array}{c}\text { Correlation } \\
\text { coefficient } \\
\text { With the } \\
\text { domain }\end{array}$ & $\begin{array}{c}\text { Paragraph } \\
\text { no. }\end{array}$ & $\begin{array}{c}\text { Correlation } \\
\text { coefficient } \\
\text { With the } \\
\text { domain }\end{array}$ & $\begin{array}{c}\text { Paragraph } \\
\text { no. }\end{array}$ & $\begin{array}{c}\text { Correlation } \\
\text { coefficient } \\
\text { With the } \\
\text { domain }\end{array}$ & $\begin{array}{c}\text { Paragraph } \\
\text { no. }\end{array}$ & $\begin{array}{c}\text { Correlation } \\
\text { coefficient } \\
\text { With } \\
\text { the } \\
\text { domain }\end{array}$ \\
\hline $\mathbf{1}$ & .476 & $\mathbf{1 3}$ & .833 & $\mathbf{2 5}$ & .783 & $\mathbf{3 7}$ & .544 \\
\hline $\mathbf{2}$ & .773 & $\mathbf{1 4}$ & .745 & $\mathbf{2 6}$ & .679 & $\mathbf{3 8}$ & .522 \\
\hline $\mathbf{3}$ & .822 & $\mathbf{1 5}$ & .742 & $\mathbf{2 7}$ & .716 & $\mathbf{3 9}$ & .718 \\
\hline $\mathbf{4}$ & .869 & $\mathbf{1 6}$ & .725 & $\mathbf{2 8}$ & .707 & $\mathbf{4 0}$ & .632 \\
\hline $\mathbf{5}$ & .869 & $\mathbf{1 7}$ & .606 & $\mathbf{2 9}$ & .571 & $\mathbf{4 1}$ & .661 \\
\hline $\mathbf{6}$ & .845 & $\mathbf{1 8}$ & .529 & $\mathbf{3 0}$ & .648 & $\mathbf{4 2}$ & .689 \\
\hline $\mathbf{7}$ & .682 & $\mathbf{1 9}$ & .406 & $\mathbf{3 1}$ & .563 & $\mathbf{4 3}$ & .668 \\
\hline $\mathbf{8}$ & .857 & $\mathbf{2 0}$ & .786 & $\mathbf{3 2}$ & .509 & $\mathbf{4 4}$ & .592 \\
\hline $\mathbf{9}$ & .610 & $\mathbf{2 1}$ & .875 & $\mathbf{3 3}$ & .447 & $\mathbf{4 5}$ & .490 \\
\hline $\mathbf{1 0}$ & .745 & $\mathbf{2 2}$ & .882 & $\mathbf{3 4}$ & .520 & $\mathbf{4 6}$ & .493 \\
\hline $\mathbf{1 1}$ & .774 & $\mathbf{2 3}$ & .694 & $\mathbf{3 5}$ & .358 & $\mathbf{4 7}$ & .456 \\
\hline $\mathbf{1 2}$ & .849 & $\mathbf{2 4}$ & .652 & $\mathbf{3 6}$ & .095 & & \\
\hline
\end{tabular}

It should be noted that all correlation coefficients were of acceptable and statistically significant degrees, and therefore none of these paragraphs was deleted.

Third: The stability of the questionnaire:

The researcher calculated the stability by the Alpha-Cronbach method as follows:

Table (2)

Results of the stability-coefficients for the alpha-Cronbach coefficient

\begin{tabular}{|l|c|c|}
\hline \multicolumn{1}{|c|}{ Field } & $\begin{array}{c}\text { Paragraph } \\
\text { no. }\end{array}$ & $\begin{array}{c}\text { alpha- } \\
\text { Cronbach }\end{array}$ \\
\hline The location of values in university education & 8 & .91 \\
\hline Methods and methods that can be used to develop values & 9 & .90 \\
\hline Motives for caring for values in university education & 5 & .76 \\
\hline Values of importance in university education & 14 & .84 \\
\hline $\begin{array}{l}\text { The role of university education on the value change of } \\
\text { undergraduates }\end{array}$ & 11 & .81 \\
\hline
\end{tabular}

It is clear from the results of Table (2) that all coefficients of scale stability are high, and these results indicate the validity of the questionnaire for use in the current research.

Fourth: The statistical standard: 
The Likert five-step scale was adopted to correct the study tools, by giving each of its paragraphs one of the five grades (strongly agree, agree, neutral, disagree, strongly disagree) and they are digitally represented $(5,4,3,2,1)$, respectively, The following scale was adopted for the purposes of analyzing the results, as in Table (3).

Judging responses using the Likert five-way scale

\begin{tabular}{|c|r|}
\hline Range & Level \\
\hline $2.33-1.00$ & Low \\
\hline $3.67-2.34$ & Moderate \\
\hline $5.00-3.68$ & High \\
\hline
\end{tabular}

Fifth: Frequencies and percentages to describe the study sample

The sample of the study was distributed as follows:

Table No. (4)

Frequencies and percentages according to the study variables

\begin{tabular}{|c|r|r|c|}
\hline Variables & Categories & Repetition & Percentage \\
\hline \multirow{2}{*}{ Gender } & Male & 238 & 62.6 \\
\cline { 2 - 4 } & female & 142 & 37.4 \\
\hline \multirow{3}{*}{ Age } & From 18 - less than 20 & 104 & 27.4 \\
\cline { 2 - 4 } & From 20 - less than 21 & 104 & 27.4 \\
\cline { 2 - 4 } & From 21 - less than 22 & 103 & 27.1 \\
\hline \multirow{2}{*}{ Academic level } & More than 22 & 69 & 18.2 \\
\cline { 2 - 4 } & first year & 104 & 27.4 \\
\cline { 2 - 4 } & Second Year & 104 & 27.4 \\
\cline { 2 - 4 } & third year & 103 & 27.1 \\
\hline \multirow{2}{*}{ Collage } & Fourth year and more & 69 & 6.2 \\
\cline { 2 - 4 } & Humanities colleges & 254 & 33.2 \\
\hline
\end{tabular}

Calculating the arithmetic mean and the standard deviations for the fields and the paragraphs related to each field. - After applying the questionnaire to the study sample and emptying the responses, the arithmetic mean and standard deviations for the fields and the paragraphs related to each field were calculated, and the tables below show that.

\section{Table (5)}

Arithmetic mean and standard deviations for fields of the role of university education in social and value change for King Abdulaziz University students in Jeddah in descending order according to their arithmetic mean.

\begin{tabular}{|c|c|l|c|c|c|}
\hline Rank & No. & \multicolumn{1}{|c|}{ Fields } & $\begin{array}{c}\text { Arithmetic } \\
\text { mean }\end{array}$ & $\begin{array}{c}\text { standard } \\
\text { deviation }\end{array}$ & Level \\
\hline 1 & 3 & $\begin{array}{l}\text { Motives for caring for values in university } \\
\text { education }\end{array}$ & 3.97 & .880 & High \\
\hline 2 & 2 & $\begin{array}{l}\text { Methods and methods that can be used to develop } \\
\text { values }\end{array}$ & 3.76 & .811 & High \\
\hline 3 & 5 & $\begin{array}{l}\text { The role of university education on the value } \\
\text { change of undergraduates }\end{array}$ & 3.66 & .822 & Moderate \\
\hline 4 & 1 & The location of values in university education & 3.61 & 1.085 & Moderate \\
\hline 5 & 4 & Values of importance in university education & 3.57 & .799 & Moderate \\
\hline
\end{tabular}

Table (5) shows that the arithmetic mean ranged between (3.57-3.97), where the area of motivations for interest in values in university education came in the first place with the highest arithmetic mean of (3.97), while the field of values of importance in university education came in the last rank with an average My account reached (3.57).

The first field: The location of values in university education

Mathematical averages and standard deviations for the paragraphs related to the location of values field in university education were extracted, and the table below shows that. 
Table (6)

Arithmetic mean and standard deviations for paragraphs related to the location of values field in university education are arranged in descending order according to their arithmetic mean.

\begin{tabular}{|c|c|c|c|c|c|}
\hline Rank & No. & Fields & $\begin{array}{l}\text { Arithmetic } \\
\text { mean }\end{array}$ & $\begin{array}{l}\text { standard } \\
\text { deviation }\end{array}$ & Level \\
\hline 1 & 1 & $\begin{array}{l}\text { The importance of university education in social } \\
\text { change increases the importance of the position of } \\
\text { values in graduate personalities. }\end{array}$ & 4.17 & 1.077 & High \\
\hline 2 & 2 & $\begin{array}{l}\text { There is no university education course that does not } \\
\text { have a valuable dimension }\end{array}$ & 3.86 & 1.326 & High \\
\hline 3 & 3 & $\begin{array}{l}\text { The focus of university education on cognitive and } \\
\text { professional preparation does not leave room for } \\
\text { concern with values issues }\end{array}$ & 3.77 & 1.298 & High \\
\hline 4 & 4 & $\begin{array}{l}\text { The university student has achieved positive or } \\
\text { negative growth in values, and there is no way to } \\
\text { change it }\end{array}$ & 3.66 & 1.484 & Moderate \\
\hline 5 & 7 & $\begin{array}{l}\text { Development of values is a task of school education, } \\
\text { not university. }\end{array}$ & 3.51 & 1.385 & Moderate \\
\hline 6 & 5 & $\begin{array}{l}\text { The independence of the student's personality enables } \\
\text { him to review the values that he previously dreamed } \\
\text { of, so that he adopts the values he now sees with } \\
\text { conviction and choice. }\end{array}$ & 3.43 & 1.466 & Moderate \\
\hline 7 & 6 & $\begin{array}{l}\text { The relative nature of values requires that the subject } \\
\text { of values be left to personal choice }\end{array}$ & 3.33 & 1.553 & Moderate \\
\hline 8 & 8 & $\begin{array}{l}\text { University education environment and methods } \\
\text { compared to other education environments require an } \\
\text { important location for values in more than those } \\
\text { environments }\end{array}$ & 3.14 & 1.465 & Moderate \\
\hline
\end{tabular}

Table (6) shows that the arithmetic averages ranged between (3.14-4.17), as Paragraph No. (1) stated that "The importance of university education in social change increases the importance of the position of values in graduate personalities." In the first rank with an arithmetic mean of (4.17), while paragraph (8) which reads "The environment of university education and its methods compared to environments" came with the last rank and with an average of (3.14).

The second area: methods and methods that can be used to develop values

Mathematical averages and deviations are extracted for the paragraphs of the methods and methods that can be used to develop values, and the table below illustrates this.

Table (7)

Arithmetic mean and standard deviations for paragraphs related to the field of methods and methods that can be used to develop values in descending order according to their arithmetic mean.

\begin{tabular}{|c|c|c|c|c|c|}
\hline Rank & No. & Fields & $\begin{array}{l}\text { Arithmetic } \\
\text { mean }\end{array}$ & $\begin{array}{l}\text { standard } \\
\text { deviation }\end{array}$ & Level \\
\hline 1 & 16 & $\begin{array}{l}\text { Providing opportunities for dialogue and discussion } \\
\text { on the value dimensions of the academic content }\end{array}$ & 4.25 & .852 & High \\
\hline 2 & 17 & $\begin{array}{l}\text { Comparing the positive, commendable values and } \\
\text { corresponding forms of disparaging behavior }\end{array}$ & 4.10 & .995 & High \\
\hline 3 & 14 & $\begin{array}{l}\text { Giving scientific subjects their right when exposed } \\
\text { to the value dimensions of these subjects }\end{array}$ & 4.06 & .967 & High \\
\hline 4 & 13 & $\begin{array}{l}\text { Allocating readings and duties that are concerned } \\
\text { with the value aspect of academic study topics }\end{array}$ & 3.86 & 1.150 & High \\
\hline 5 & 15 & Employing strategies for teaching values & 3.83 & 1.269 & High \\
\hline 6 & 11 & $\begin{array}{l}\text { Provide positive examples and examples of the } \\
\text { results of adherence to good values }\end{array}$ & 3.55 & 1.082 & Moderate \\
\hline 7 & 12 & $\begin{array}{l}\text { Calendar methods and tools include attitudes } \\
\text { related to students' ethical behavior }\end{array}$ & 3.50 & 1.147 & Moderate \\
\hline 8 & 9 & $\begin{array}{l}\text { Allow students to express their opinions and } \\
\text { positions freely }\end{array}$ & 3.34 & 1.383 & Moderate \\
\hline 9 & 10 & $\begin{array}{l}\text { Personal behavior that is compatible with good } \\
\text { values, as the teacher is an example }\end{array}$ & 3.31 & 1.075 & Moderate \\
\hline
\end{tabular}


Table (7) shows that the arithmetic mean ranged between (3.31-4.25), as paragraph (16) states that "providing opportunities for dialogue and discussion about the value dimensions of the academic content" came first and with an average of (4.25), while it came Paragraph No. (10), which reads: "Personal behavior consistent with good values, given that the teacher is a model and role model", at the last rank, with an average of (3.31).

The third field: motives for caring for values in university education

Mathematical averages and standard deviations were extracted for the paragraphs of the motives for interest in values in university education, and the table below shows that.

(Table 8)

Arithmetic mean and standard deviations for the paragraphs related to the field of motivations for interest in values in university education are arranged in descending order according to their arithmetic mean.

\begin{tabular}{|c|c|l|c|c|c|}
\hline Rank & No. & \multicolumn{1}{|c|}{ Fields } & $\begin{array}{c}\text { Arithmetic } \\
\text { mean }\end{array}$ & $\begin{array}{c}\text { standard } \\
\text { deviation }\end{array}$ & Level \\
\hline 1 & 18 & Attention promoting values is a religious duty & 4.03 & .901 & High \\
\hline 2 & 21 & Caring for values is part of professional and career work & 4.01 & 1.328 & High \\
\hline 3 & 20 & $\begin{array}{l}\text { Addressing value issues contributes to obtaining appreciation } \\
\text { from others }\end{array}$ & 3.99 & 1.322 & High \\
\hline 4 & 19 & $\begin{array}{l}\text { Promoting values contributes to achieving psychological } \\
\text { happiness }\end{array}$ & 3.93 & .992 & High \\
\hline 5 & 22 & Convincing that values are virtues in themselves & 3.92 & 1.498 & High \\
\hline
\end{tabular}

Table (8) shows that the arithmetic averages ranged between (3.92-4.03), where paragraph (18), which states "interest in promoting the values of religious duty" came first and with an average of (4.03), while paragraph (22) It reads "the conviction that the values are virtues in their own right", at the last rank, with an average of (3.92).

Fourth Domain: Values of Importance in University Education

Mathematical averages and standard deviations were extracted for the paragraphs related to the field of values of importance in university education, and the table below illustrates this.

Table 9

Arithmetic averages and standard deviations for paragraphs related to the field of values of importance in university education are arranged in descending order according to their arithmetic mean.

\begin{tabular}{|c|c|c|c|c|c|}
\hline Rank & No. & Fields & $\begin{array}{l}\text { Arithmetic } \\
\text { mean }\end{array}$ & $\begin{array}{l}\text { standard } \\
\text { deviation }\end{array}$ & Level \\
\hline 1 & 31 & Creativity and excellence in performance and behavior & 3.89 & 1.180 & High \\
\hline 2 & 29 & $\begin{array}{l}\text { The student's affiliation with the community and the } \\
\text { nation }\end{array}$ & 3.85 & 1.359 & High \\
\hline 3 & 32 & $\begin{array}{l}\text { Take advantage of the opportunity of university education } \\
\text { to acquire the best possible preparation for the profession } \\
\text { being learned }\end{array}$ & 3.75 & 1.446 & High \\
\hline 4 & 28 & $\begin{array}{l}\text { Respecting the opinions of others and preparing to listen } \\
\text { and understand them }\end{array}$ & 3.72 & 1.275 & High \\
\hline 5 & 30 & $\begin{array}{l}\text { Personal responsibility for community reform and } \\
\text { development }\end{array}$ & 3.69 & 1.256 & High \\
\hline 6 & 23 & Belonging to the university and preserving its properties & 3.66 & 1.552 & Moderate \\
\hline 7 & 35 & $\begin{array}{l}\text { The responsibility is towards building a new family and } \\
\text { getting ready to take on its burden }\end{array}$ & 3.58 & 1.505 & Moderate \\
\hline 8 & 24 & $\begin{array}{l}\text { Attention to students, professors, and workers, and a } \\
\text { positive feeling towards them }\end{array}$ & 3.49 & 1.421 & Moderate \\
\hline 9 & 33 & $\begin{array}{l}\text { Responsibility towards the family and its efforts to } \\
\text { educate their children in universities }\end{array}$ & 3.46 & 1.302 & Moderate \\
\hline 10 & 26 & $\begin{array}{l}\text { Commitment to honesty and integrity in the positions of } \\
\text { university tests and the calendar }\end{array}$ & 3.44 & 1.395 & Moderate \\
\hline 11 & 27 & Freedom to express opinions and take positions & 3.38 & 1.532 & Moderate \\
\hline 12 & 36 & $\begin{array}{l}\text { Estimate the value of uncle and knowledge as basic goals } \\
\text { for university education }\end{array}$ & 3.37 & 1.444 & Moderate \\
\hline 13 & 34 & $\begin{array}{l}\text { Chastity and virtue in thinking and dealing with the } \\
\text { opposite sex }\end{array}$ & 3.33 & 1.442 & Moderate \\
\hline 14 & 25 & Body and clothing hygiene & 3.30 & 1.573 & Moderate \\
\hline
\end{tabular}


Table (9) shows that the arithmetic mean ranged between (3.30-3.89), as paragraph (31) which states "creativity and excellence in performance and behavior" came first and with an average of (3.89), while paragraph (25) And it reads, "Cleanliness in body and clothing", at the last rank, with an average score of (3.30).

Fifth Domain: The role of university education on the value change of undergraduates

Arithmetic mean and standard deviations were extracted for the paragraphs related to the field of university education role on the significant change of undergraduates, and the table below shows that.

Table (10)

Arithmetic mean and standard deviations of the paragraphs related to the field of university education on the value change of undergraduates, arranged in descending order according to their arithmetic mean

\begin{tabular}{|c|c|c|c|c|c|}
\hline Rank & No. & Fields & $\begin{array}{l}\text { Arithmetic } \\
\text { mean }\end{array}$ & $\begin{array}{c}\text { standard } \\
\text { deviation }\end{array}$ & Level \\
\hline 1 & 41 & $\begin{array}{l}\text { Youth recognize the importance of the value of } \\
\text { working in one team }\end{array}$ & 3.87 & 1.343 & High \\
\hline 2 & 45 & $\begin{array}{l}\text { Skilled preparation in line with the developments } \\
\text { of the times. }\end{array}$ & 3.86 & 1.280 & High \\
\hline 3 & 42 & Accept technology and perfect its use and use & 3.68 & 1.282 & High \\
\hline 4 & 40 & $\begin{array}{l}\text { The practice of youth elections in the university } \\
\text { deepens the value of democracy }\end{array}$ & 3.67 & 1.442 & Moderate \\
\hline 5 & 44 & $\begin{array}{l}\text { Developing the ability of young people to } \\
\text { contribute to making the political future. }\end{array}$ & 3.66 & 1.357 & Moderate \\
\hline 5 & 47 & $\begin{array}{l}\text { Valuable behavior in God, the believer, is } \\
\text { preparation }\end{array}$ & 3.66 & 1.382 & Moderate \\
\hline 7 & 39 & $\begin{array}{l}\text { Educating the youth about the importance of the } \\
\text { value of belonging to the country }\end{array}$ & 3.65 & 1.541 & Moderate \\
\hline 8 & 43 & $\begin{array}{l}\text { Interest in volunteering to train young people to } \\
\text { love manual labor }\end{array}$ & 3.63 & 1.388 & Moderate \\
\hline 9 & 46 & $\begin{array}{l}\text { To develop youth leadership and involve them in } \\
\text { the decision-making process }\end{array}$ & 3.62 & 1.438 & Moderate \\
\hline 10 & 37 & $\begin{array}{l}\text { Training the youth in the democratic style in } \\
\text { practicing student activities inside the university }\end{array}$ & 3.56 & 1.458 & Moderate \\
\hline 11 & 38 & $\begin{array}{l}\text { Youths practice cultural activities to counter new } \\
\text { values that do not fit society's values }\end{array}$ & 3.43 & 1.460 & Moderate \\
\hline
\end{tabular}

Table (10) shows that the arithmetic mean ranged between (3.43-3.87), where paragraph No. (41) stipulates "creativity is the awareness of young people of the importance of the value of work in one team" in the first place with an arithmetic mean of (3.87), while it came Paragraph No. (38), which reads: "Youth's practice of cultural activities to counter new values that do not fit society's values." Last rank, with an average score of (3.43).

6- Using the multiple contrast analysis test to reveal the differences between the views of the study sample according to their personal variables.

- Are there statistically significant differences at the level of significance $(0.05 \leq \alpha)$ of the role of university education in the change in Saudi society due to the gender, age, and educational level from the viewpoint of students of King Abdulaziz University in Jeddah?

To answer this question, arithmetic averages and standard deviations for the role of university education in the change in Saudi society due to the variable of gender, age, and educational level were extracted from the point of view.

The consideration of King Abdulaziz University students in the city of Jeddah and the table below shows that. 
Table No. (11)

Arithmetic mean and standard deviations of the role of university education in the change in Saudi society according to variables gender, age, and educational level

\begin{tabular}{|c|c|c|c|c|}
\hline Variables & Category & Arithmetic mean & standard deviation & No. \\
\hline Gender & $\begin{array}{l}\text { Male } \\
\text { Female }\end{array}$ & $\begin{array}{l}3.65 \\
3.68\end{array}$ & $\begin{array}{l}.816 \\
.834\end{array}$ & $\begin{array}{l}238 \\
142\end{array}$ \\
\hline Age & $\begin{array}{l}\text { From } 18 \text { - less than } 20 \\
\text { From } 20 \text { - less than } 21 \\
\text { From } 21 \text { - less than } 22 \\
\text { More than } 22\end{array}$ & $\begin{array}{l}3.67 \\
3.70 \\
3.60 \\
3.68\end{array}$ & $\begin{array}{l}.817 \\
.818 \\
.808 \\
.867\end{array}$ & $\begin{array}{c}104 \\
104 \\
103 \\
69\end{array}$ \\
\hline Academic level & $\begin{array}{r}\text { first year } \\
\text { Second Year } \\
\text { third year } \\
\text { Fourth year and more }\end{array}$ & $\begin{array}{l}3.67 \\
3.70 \\
3.60 \\
3.68\end{array}$ & $\begin{array}{l}.817 \\
.818 \\
.808 \\
.867\end{array}$ & $\begin{array}{c}104 \\
\\
104 \\
103 \\
69\end{array}$ \\
\hline
\end{tabular}

Table (11) shows an apparent variation in arithmetic averages and standard deviations of the role of university education in the change in Saudi society according to gender, age, and educational level from the viewpoint of King Abdulaziz University students in Jeddah and to indicate the significance of the statistical differences between the arithmetic means. Multiplayer Schedule (12).

Table No. (12)

Analysis of the multiple mono-variance of the impact of the gender, age, and educational level of the role of university education in change in Saudi society from the viewpoint of students of King Abdulaziz University in Jeddah

\begin{tabular}{|l|c|c|c|c|c|}
\hline $\begin{array}{c}\text { Source of } \\
\text { contrast }\end{array}$ & $\begin{array}{c}\text { Sum of } \\
\text { squares }\end{array}$ & $\begin{array}{c}\text { Degrees of } \\
\text { freedom }\end{array}$ & $\begin{array}{c}\text { Average } \\
\text { squares }\end{array}$ & $\begin{array}{c}\text { F } \\
\text { Value }\end{array}$ & $\begin{array}{c}\text { Statistical } \\
\text { significance }\end{array}$ \\
\hline Gender & .048 & 1 & .048 & .071 & .790 \\
Age & .532 & 3 & .177 & .261 & .853 \\
Academic & .532 & 3 & .177 & .261 & .853 \\
level & 255.435 & 376 & .679 & & \\
Error & 255.967 & 379 & & & \\
Total & & & & \\
\hline
\end{tabular}

Table (12) shows the following:

- There were no statistically significant differences $(\alpha \leq 0.05)$ due to the effect of the species, as the value of ..071 and statistical significance amounted to .790 .

- There were no statistically significant differences $(\alpha \leq 0.05)$ due to the effect of age, as the value of P.261 and the statistical significance amounted to .853 .

- There were no statistically significant differences $(\alpha \leq 0.05)$ due to the effect of the educational level, as the value of P.261 and the statistical significance amounted to .853 .

\section{Results}

The results of the study showed that there is a position that the values in university education obtained a high average of appreciation, as the study found the importance of university education in social change.

The results of the study also showed that it is one of the most important methods and methods that can be used to develop values

It is to provide opportunities for dialogue and discussion about the value dimensions of the academic content, and to give scientific subjects their right when exposed to the value dimensions of these topics, and include methods of evaluation and tools related to the values of students' behavior, in addition to allowing students to express their views and positions freely.

The study also showed that one of the most important motives for caring for values in university education was the interest in promoting values as a religious duty, and attention to values is part of the professional and job work, and addressing issues of values contributes to obtaining appreciation of others, in addition to strengthening values contribute to achieving psychological happiness, and the conviction that Values are virtues in their own right. 
The study showed that the most important values of university education are creativity and excellence in performance and behavior, the student's loyalty to society and the nation and the benefit of the opportunity of university education in acquiring the best possible preparation for the profession being learned, respecting the opinions of others and preparing to listen to and understand them, personal responsibility for community reform And its development.

Belonging to the university and preserving its properties.

The role of university education is the value change of undergraduates by the awareness of young people of the importance of the value of work in one team, and the skillful preparation in line with the developments of the times.

Acceptance of technology, mastery of its use and employment, and the practice of youth in elections within the university deepens the value of democracy.

\section{Recommendations}

- The researcher recommends paying attention to university values, given that university youth live a value double standard between thought and practice, and there is a justifiable trend for some socially unlawful behaviors.

\section{Conclusion}

At the end of the research, university education is the role of university education in social and value change for students of King Abdulaziz University in the city of Jeddah, as university education plays an important role in developing cultural awareness among members of society about issues pertaining to the nation, which takes a large part of public opinion attention, and Students also learn through it methods and etiquette of dialogue and its ability to assimilate, to think in good ways, and to move away from randomness in decision-making

\section{References}

- Al-Swalqa, Rola Odeh (2016), Social change and the value struggle of educated women in Jordanian society, a comparative study, studies, humanities and social sciences, University of Jordan, volume 43, annex 5.

- $\quad$ Badawi, Ahmed Zaki (1990) Lexicon of Social Sciences, Lebanon Library, Beirut.

- $\quad$ Bayoumi, Mohamed Ahmed (2005) Sociology of Values, University Knowledge House, Alexandria.

- Bayoumi, Mohamed Ahmed (2012) Cultural Sociology, Dar Al-Ma'arif Al-Jama'ia, Alexandria

- Taawainat, Halima (2015) The Value and Directional Change of Higher Education Students Moving from Rural to City, Journal of Humanities and Social Sciences, No. 18.

- Jamal, Tali (2016): The Values Change in the University Sect. Field Study on a Sample of University Students, Al-Messila Magazine, Journal of Social Studies and Research, University of the Martyr Hama Lakhdar - AlWadi - Issue 20.

- Hegazy, Izzat (2005) Arab youth and its problems, World of Knowledge Series, Kuwait, No. 06.

- Hammad, Nour El-Hoda (2015), Higher Education and Technology as a Leverage for Social and Economic Change in Societies, a research paper presented at the works of the Ninth International Conference, Algeria.

- Hammad, Nour El-Hoda (2015), Higher Education and Technology as a Leverage for Social and Economic Change in Societies, a research paper presented at the works of the Ninth International Conference, Algeria.

- Hamad Omar Al-Tounoubi, Social Change, Al-Maaref Establishment, Alexandria, Jalal Hazy and Associates, Alexandria University, C.M. P, Omar Al-Mukhtar University, Libya, 1996.

- Al-Khuriji, Abdullah, (1983), Social and Cultural Change, First Edition, Jeddah.

- Al-Khuriji, Abdullah, (1983), Social and Cultural Change, First Edition, Jeddah

- Khalil, El-Rahman Abdel-Rahman, (2003), the role of the events of September 11 in changing attitudes towards other peoples, Journal of Arab Studies in Psychology, Volume 2, No. 1.

- Khalil, El-Rahman Abdel-Rahman, (2003), the role of the events of September 11 in changing attitudes towards other peoples, Journal of Arab Studies in Psychology, Volume 2, No. 1.

- Al-Diqas, Muhammad, (1996), Social Change between Theory and Practice, 2nd floor, Dar Majdalawi, Amman, Jordan.

- Al-Diqas, Muhammad, (1996), Social Change between Theory and Practice, 2nd floor, Dar Majdalawi, Amman, Jordan.

- Al-Rishi, Ibtisam bin Aziz bin Abdulaziz (2011), a proposed vision to confront the effects of social change on the educational role of the Saudi family in Jeddah from an Islamic educational perspective, MA, Umm AlQura University, Makkah Al-Mukarramah, Kingdom of Saudi Arabia.

- Al-Rishi, Ibtisam bin Aziz bin Abdulaziz (2011), a proposed vision to confront the effects of social change on the educational role of the Saudi family in Jeddah from an Islamic educational perspective, MA, Umm AlQura University, Makkah Al-Mukarramah, Kingdom of Saudi Arabia.

- Zureikat, Murad bin Ali (2007), Social Change for Ibn Khaldun, a working paper presented to the Ibn Khaldun 
symposium held by the Saudi Society for Sociology, Naif Arab University for Security Sciences, Riyadh.

- Zureikat, Murad bin Ali (2007), Social Change for Ibn Khaldun, a working paper presented to the Ibn Khaldun symposium held by the Saudi Society for Sociology, Naif Arab University for Security Sciences, Riyadh.

- Zumoom, Khaled, (2009), The Value Change in Social Marketing Campaigns, A Critical Study on Folders Campaigns in the Emirates Society, University of Sharjah, University Library.

- $\quad$ Salim, Shaker Mustafa (1981) Dictionary of Anthropology, Kuwait University, Kuwait.

- $\quad$ Saliba, Jamil (1973) The Philosophical Dictionary, Dar Al-Lebnani, Biot, Part 2.

- Drummer, Latifa (2012) Social Change and its Role in Changing Social Values, Journal of Humanities and Social Sciences, Issue No. 8.

- Abdul Aziz bin Ali Al-Ghareeb (2016), Social and cultural change with applied models from Saudi society, published study, Al-Khwarizm scientific publishers and libraries in Riyadh.

- Abdul Aziz bin Ali Al-Ghareeb (2016), Social and cultural change with applied models from Saudi society, published study, Al-Khwarizm scientific publishers and libraries in Riyadh.

- Al-Aqili, Mazen et al., (2007), The role of universities in changing the political culture of students, a field study at Mu'tah University, Al-Nahdah Magazine, volume eight, number three.

- Al-Aqili, Mazen et al., (2007), The role of universities in changing the political culture of students, a field study at Mu'tah University, Al-Nahdah Magazine, volume eight, number three.

- Omar, Maan Khalil (2004) Dar Al-Shorouk for Publishing and Distribution, Amman.

- Ghaith, Muhammad Khalil (1987) Social Change and Planning, University Knowledge House, Egypt.

- Muhammad, Abdul Latif (1999) Raising Values, World of Knowledge Series, Kuwait, No. 160.

- Muhammad, Muhammad Ali (1999) Arab Youth and Social Change, Arab Renaissance House, Beirut.

- Bin Ramadan, Samia (2013) The Value Change and its Impact on the Attitudes of Youth in Algerian Society between Reality and Future Challenges, Journal of Humanities and Society, Algeria, No. 12..

- Corriero, Jennifer,(2004) Role of Youth Survey, TakingI TGlobal

- El-Bahnasawy,N. (2008), Empirical examination of the determinants : cross- sectional and panel analysis, Unpublished ph, Dissertation, Department of economics Colorado state University .

- $\quad$ Larrain, J. (1989), Theories of Development: Capitalism, Colonialism

- $\quad$ and Dependency. Cambridge, MA.: Polity Press.

- $\quad$ Owens, Patsy Eubanks, Rochelle, Maggie La, Nelson, Alyssa A, Montgomery- Block, Kindra,(2011), Youth Voices Influencing Local and Regional Change, Children, Youth \& Environments; Vol. 21 Issue 1, p253274, 22p.

- $\quad$ Roos,Fitzoerald,(1977),Human Needs and Politics, Pergamon Press Hong Kong, P,163.

- $\quad$ Mueller, D.j\&Wornhoff, S.A. (2005). Distinguishing Personal \& Social Values. Chicago: University Of Chicago Press. 